\title{
KONTRAK ELEKTRONIK DALAM PERDAGANGAN INTERNASIONAL DITINJAU DARI PERSPEKTIF HUKUM POSITIF INDONESIA
}

\author{
Derry Angling Kesuma \\ Sumpah Pemuda School of Law (STIHPADA) Palembang, Indonesia \\ Email: kesumaderry@gmail.com
}

\begin{abstract}
Abstrak
Pertumbuhan perdagangan dan perdagangan internasional efek dari perkembangan teknologi dalam sepuluh hingga lima belas tahun terakhir, yang biasa disebut dengan istilah "globalisasi" telah mengubah persepasi pemerintah dan para pelaku bisnis internasional dengan mencari harmonisasi antara hukum positif dan ekonomi. Penelitian ini berjenis penelitian kualitatif dengan pendekatan yusridis-normatif. Data dalam penelitian ini berupa data sekunder yang dikumpulkan melalui metode studi pustaka. Penelitian ini menekankan pada pemahaman kontrak elektronik dari perspektif hukum positif dalam konteks hubungan dagang internasional. Dari penelitian ini, dapat diketahui bahwa Aturan tentang kontrak elektronik mengenai Perdagangan Internasional di Indonesia masih diatur dalam UU Nomor 11 Tahun 2008 tentang ITE dan UU Nomor 19 Tahun 2001 tentang Perubahan atas UU Nomor 11 Tahun 2011 tentang ITE.
\end{abstract}

Kata Kunci: Kontrak Elektronik, Perdagangan, Hukum Positif.

\begin{abstract}
The growth of international trade and trade as a result of technological developments in the last ten to fifteen years, which is commonly referred to as "globalization" has changed the perception of governments and international business people by seeking harmonization between positive law and economics. This research is a qualitative research with a juridicalnormative approach. The data in this study are secondary data collected through the literature study method. This study emphasizes the understanding of electronic contracts from a positive legal perspective in the context of international trade relations. From this research, it can be seen that the rules regarding electronic contracts regarding International Trade in Indonesia are still regulated in Law Number 11 of 2008 concerning ITE and Law Number 19 of 2001 concerning Amendments to Law Number 11 of 2011 concerning ITE.
\end{abstract}

Keywords: Electronic Contracts, Trade, Positive Law.

\section{A. PENDAHULUAN}

Di era teknologi ini, komunikasi internet menjadi sangat penting yang menyebabkan masalah hukum di hampir setiap aspek kehidupan manusia yang berhubungan dengan elektronik. Transaksi komersial secara fisik serta aktivitas bisnis kini telah berubah menjadi transaksi online atau elektronik, mendorong legislator di seluruh dunia untuk mengikuti perkembangan ini dengan memberlakukan undang-undang atau hukum positif untuk mengatur hal tersebut (Akhmaddhian \& Agustiwi, 2016). Salah satu masalah yang paling penting menyangkut dan melibatkan hukum dan yurisdiksi yang berlaku ketika konflik muncul yang melibatkan kontrak internasional yang sah dan diakui. Hal tersebut tentu saja 
memfasilitasi transaksi online untuk membuka jalan bagi munculnya kontrak yang dibuat melalui sarana elektronik (Hanim, 2011).

Tentu saja, seiring berjalannya waktu dan perkembangan masyarakat telah banyak berubah. Tujuan peningkatan kepastian hukum dan prediktabilitas masih menjadi pendorong utama upaya harmonisasi hukum dagang internasional (Hasoloan, 2013). Namun, pengalaman dengan harmonisasi hukum dan meningkatnya minat para peneliti hukum untuk mencari harmonisasi hubungan antara hukum dan ekonomi telah menghasilkan argumen tambahan. Secara khusus, argumen yang berkaitan dengan peran positif harmonisasi hukum dalam mengurangi biaya transaksi dan memfasilitasi bisnis di seluruh dunia (Khairandy, 2011).

Dalam praktik kerjasama bisnis internasional, para pebisnis dipastikan memerlukan kontrak elektronik bisnis internasional, hal ini terjadi baik dalam: (1) Skema bilateral pemerintah dengan pemerintah $(G$ to $G)$, (2) Antara pemerintah dengan swasta $(G$ to $B)$, ataupun (3) hubungan horizontal antar swasta ( $B$ to $B$ ) (Latianingsih, 2012). Namun dalam praktiknya di lapangan, masih terdapat sengketa dan masalah hukum mengenai kerjasama dan transaksi bisnis internasional. Hal tersebut berdampak pada kerugian bisnis di berbagai bidang, alih-alih memberi keuntungan bagi pelaku bisnis (Malian, 2004).

Berdasarkan kerangka acuan yang ditetapkan oleh Majelis Umum PBB, UNCITRAL memberikan mandatnya dengan: 1) Mengkoordinasikan pelaku bisnis yang aktif di bidang ini dan mendorong kerja sama di antara pelaku bisnis lintas negara; 2) Memastikan keseragaman interpretasi dan penerapan konvensi internasional dan hukum yang seragam di bidang perdagangan internasional; 3) Menyebarluaskan informasi mengenai legislasi nasional serta perkembangan hukum modern di bidang Internasional Trade Law; 4) Membuat kebijakan lain yang berguna untuk memperbaiki Internasional Trade Law yang berlaku (Manap, 208).

Dalam kontrak internasional, ada kecenderungan untuk tidak dapat memberikan informasi yang cukup dalam kerjasama tersebut yang diperlukan untuk kontrak elektronik (Nurhafni \& Bintang, 2018). Pemerintah Indonesia telah melakukan intervensi untuk memperbarui ketentuan hukum tentang transaksi elektronik untuk memenuhi kebutuhan globalisasi. Pemerintah juga memberikan langkah-langkah untuk melindungi konsumen yang dianggap sebagai pihak yang lemah (Perdana \& Dahlan, 2014). Kegiatan perdagangan ini didukung oleh kemajuan dibidang teknologi, informasi, serta bidang komunikasi. Perkembangan kedua bidang tersebut memberikan daya saing untuk melakukan kegiatan perdagangan antar negara (Putri, 2018).

E-commerce dapat melibatkan transfer dana secarea elektronik, pertukaran data secara otomatis, dan sistem manajemen pengumpulan data secara otomatis (Safitriani, 2014). Kontrak elektronik juga diartikan bahwa perjanjian yang didigitalkan dengan dokumen yang dipindai atau dibuat dalam bentuk softcopy. Pendapat seperti ini adalah pendapat yang salah, kesalahpahaman lain juga terjadi dalam menafsirkan tanda tangan elektronik (Setyawati, Ali \& Rasyid, 2017). Dengan ini dapat disimpulkan bahwa penjelasan tentang kontrak elektronik, jenis, dan tanda tangan elektronik menjadi penting.

Untuk mendapatkan kepercayaan para pihak dalam mengadakan perjanjian menggunakan kontrak elektronik di bidang Perdagangan Internasional harus menggunakan aturan yang jelas yang diatur dalam Hukum Perdata Internasional yang diatur dalam hukum perdata internasional karena melibatkan aturan privat yang mensyaratkan dua pihak atau 
lebih. Hal ini untuk memberikan kepastian hukum bagi para pihak yang menggunakan perjanjian dengan menggunakan perjanjian elektronik karena ketika perjanjian dilakukan lintas negara pasti memiliki aturan hukum yang berbeda dalam mengaturnya. Untuk itu, harus ada pilihan yang tepat ketika terjadi kecelakaan dalam suatu perjanjian yang menggunakan kontrak elektronik.

Sebagai negara berdaulat, Indonesia mengikuti organisasi perdagangan dunia dan juga harus memiliki aturan yang jelas dan tegas mengenai perjanjian yang menggunakan kontrak elektronik. Di zaman sekarang ini dan segala sesuatunya, dikenal dengan pengurangan penggunaan kertas untuk melestarikan ekosistem bumi atau yang dikenal dengan paperless. Dengan semua hal tersebut, aturan hukum harus diberikan kepastian dan kejelasan agar para pihak dalam membuat perjanjian menggunakan kontrak elektronik dan mengurangi adanya sengketa hukum antar pelaku bisnis.

\section{B. METODE}

Penelitian ini adalah penelitian kualitatif dengan pendekatan yusridis-normatif. Data tersebut berupa data sekunder, data dikumpulkan melalui metode studi pustaka. Penelitian ini menekankan pada pemahaman kontrak elektronik dari perspektif hukum positif dalam konteks hubungan dagang internasional. Hukum positif sangat diperlukan bagi para pihak yang melakukan perdagangan dengan menggunakan kontrak elektronik, terutama bagi mereka yang melakukan perdagangan lintas negara melalui bisnis internasional. Selain itu, penelitian ini juga menganalisis apa saja bentuk kontrak elektronik yang sudah berlaku di Indonesia.

\section{HASIL DAN PEMBAHASAN}

\section{Problematika Kontrak Elektronik}

Hasil survei BPS tahun 2018 tentang e-commerce yang dilakukan kepada 3.504 Blok Sensus yang tersebar lebih dari 101 kabupaten/kota di seluruh provinsi Indonesia, memperlihatkan hal yang cukup menarik, yaitu sekitar 84,92\% koresponden mengandalkan sektor usaha konvensional, sisanya yaitu 15,08 telah menggunakan e-commerse. Hal ini menjadi evaluasi tersendiri kepada pemerintah, karena para pelaku usaha di Indonesia masih belum mau menggunakan teknologi digital yang kini sedang menjadi tren dalam dunia usaha. Berikut ini disajikan alasan mengapa sebagain besar pelaku usaha di Indonesia belum mau untuk ikut menggunakan teknologi elektronik sebagai salah satu jalan untuk mengembangkan usahanya: 


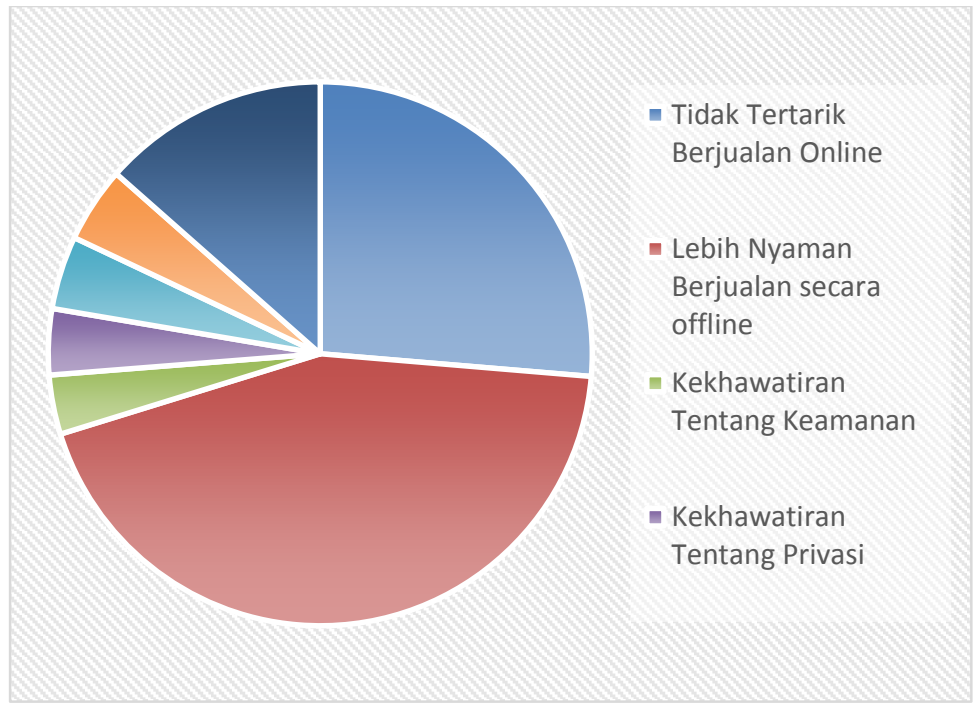

\section{Gambar 1. Persentase Usaha Tanpa E-Commerce Menurut Alasan}

Sumber: BPS (2018)

Salah satu hal yang menjadi kendala adalah mengenai teknis dari perdagangan tersebut, masyarakat banyak tidak mengetahui tentang hal yang bersifat praktis dan menjadi kebutuhan dari perdaganga di era digital ini, salah satunya tentang kontrak elektronik yang menjadi hal penting diketahui oleh para pelaku usaha. Kontrak elektronik melibatkan dua aspek utama: yaitu kecepatan dan otomatisasi. Seseorang dapat mengajukan penawaran atau penjualan dengan cepat sehingga dapat segera dikirimkan ke pihak lain. Kesalahanpahaman sering kali sulit ditangkap dan lebih sulit diperbaiki, terutama jika salah satu pihak mengandalkan kontrak. Beberapa program komputer yang mengotomatiskan tugas-tugas untuk pengguna, semakin memperumit masalah dengan membuat kontrak tanpa campur tangan manusia (Tan \& Thoen, 2003).

Contoh agen elektronik ditemukan di situs ritel Internet mana pun misalnya ketika pelanggan memesan, agen langsung menerima dan mengonfirmasi pesanan. Sementara teknologi membuat bisnis lebih cepat dan lebih mudah untuk bertransaksi, sebagian dari kecepatan ini berasal dari kurangnya interaksi formal dengan kontrak di atas kertas (Wan \& Deng, 2015). Akibatnya, kepastian dan prediktabilitas pemulihan yang diberikan oleh kontrak nyata diperumit oleh tindakan elektronik. Akibatnya, kerangka hukum internasional harus beradaptasi untuk menetapkan kepastian dan validitas yang sama untuk kontrak elektronik seperti kontrak fisik.

Konsep baru ini menciptakan peningkatan bisnis yang luas. Karena pasar lebih mudah dibuka untuk lebih banyak variasi pelaku bisnis, transaksi menjadi lebih murah, dan biaya berkurang. Para pihak yang terlibat memiliki lebih banyak kekhawatiran dengan kontrak elektronik karena hukum berhenti di perbatasan negara, sementara Internet memungkinkan bisnis untuk bebas melewati batas tersebut. Sifat unik dari kontrak elektronik menciptakan ketidakpastian dalam lingkungan hukum dan bisnis internasional karena hukum lambat merespons teknologi baru. Penerapan hukum yang ada pada perdagangan berbasis komputer seringkali tidak memadai. Perdagangan elektronik menghadirkan banyak tantangan terhadap hukum kontrak berbasis kertas, termasuk yurisdiksi, validitas, pembentukan, modifikasi, dan otentikasi. Komentar ini tidak mengeksplorasi setiap tantangan secara detail. Dasar-dasar 
pembuatan kontrak yaitu penawaran, penerimaan, dan pertimbangan, perlu dipertimbangkan dalam pembentukan kontrak elektronik dalam kesepakatan awal.

Pemerintah melalui Kementerian Perdagangan Republik Indonesia mendorong kemandirian dan otomatisasi terciptanya Perdagangan Internasional. Hal ini penting untuk menjaga daya saing alam kancah Perdagangan Internasional. Selain itu, pemerintah juga harus berperan aktif di era ekonomi digital yang berkembang pesat agar perdagangan lebih inklusif. Pemerintah harus memastikan partisipasi Indonesia dalam rantai nilai global. Sehingga dalam satu dekade terakhir, perkembangan perdagangan internasional termasuk dalam kegiatan ekonomi, atau kegiatan bisnis telah berkembang sangat pesat. Dari bentuk murni barter, jual beli, barang, komoditas (hasil pertanian, perkebunan, dan sejenisnya), atau jasa, dan hubungan perdagangan lebih kompleks.

Kemajuan teknologi informasi dalam perdagangan internasional tentunya memberikan keuntungan bagi setiap negara atau pihak yang melakukan transaksi. Keuntungan ini dapat diperoleh dari perdagangan elektronik dalam bisnis, yaitu melakukan kontrak, yang tidak harus bertemu langsung dengan para pihak untuk menyepakati. Hal ini semakin dipermudah dengan e-kontrak (kontrak elektronik), dimana kontrak dapat ditandatangani melalui media teknologi. Selain keuntungan yang bisa diperoleh, memang ada kerugian tertentu dari pihak-pihak yang menyalahgunakan kemudahan perdagangan internasional melalui teknologi informasi ini.

Di Indonesia, pengaturan e-commerce diatur dalam UU ITE. Sebaliknya, pengaturan kontrak elektronik dalam transaksi perdagangan internasional belum memiliki undangundang yang mengaturnya. Biasanya ketika ada persoalan mengenai kontrak elektronik dalam e-commerce, maka akan berpindah ke Undang-Undang Perlindungan Konsumen. Penelitian ini dilakukan untuk memberikan masukan kepada pemerintah khususnya Kementerian Perdagangan untuk membentuk aturan berupa undang-undang tentang kontrak elektronik dalam transaksi e-commerce di dunia perdagangan internasional. Dari Indonesia. Penelitian ini merupakan bagian pertama yang membahas tentang latar belakang. Bagian kedua membahas tinjauan pustaka terkait. Bagian ketiga membahas metodologi, dan bagian empat membahas data dan hasil penelitian, dan bagian kelima, yaitu kesimpulan.

Bentuk perkembangan hukum kontrak adalah e-contract yang tertulis dalam UNICITRAL Model Law on Electronic Commerce pada 1996. Kemudian pada tahun 2008, dengan berlakunya UU ITE mengenai ketentuan kontrak elektronik diakui secara hukum positif. Akan tetapi model hukum UNICITRAL dan UU ITE tidak secara eksplisit menjelaskan bentuk kontrak elektronik itu sendiri. Sehingga menimbulkan perbedaan pengetahuan dan kebingungan tentang pengertian perjanjian elektronik.

Pada umumnya orang mengira e-contract adalah kesepakatan para pihak yang dibuat melalui sistem elektronik (Pasal 1 ayat (17) UU Nomor 11 Tahun 2008 tentang UU ITE). Namun, aturan yang mengatur kontrak elektronik belum diatur secara keseluruhan dalam UU ITE. Kontrak elektronik juga diartikan bahwa perjanjian yang didigitalkan dengan dokumen yang dipindai atau dibuat dalam bentuk softcopy disebut kontrak elektronik. Pendapat seperti ini adalah pendapat yang salah karena kontrak elektronik tidak dapat dipahami. Kesalahpahaman lainnya juga ketika hendak menafsirkan electronic signature. Dengan ini dapat disimpulkan bahwa penjelasan tentang kontrak elektronik, jenis, dan electronic 
signature menjadi penting. Ditambah lagi, aturan kontrak elektronik di bidang perdagangan internasional belum diatur.

\section{Click-Wrap Agreement}

Kontrak elektronik juga terkadang disebut dengan istilah click-wrap agreement. Click-wrap Agreement ini biasanya sering ditemukan ketika user hendak meng-install sebuah software, atau mendaftarkan akun tertentu (misalnya, akun e-mail), dan sebagainya. Oleh karena itu, kontrak elektronik dapat menjadi kesepakatan antar user untuk melakukan sebuah interaksi dengan penyedia layanan yang berbasis elektronik. Namun, pihak yang ditawarkan juga tetap diberikan kehendak untuk menerima atau menolak. Dengan memfasilitasi opsi 'cancel' dan opsi 'back' biasanya disediakan juga selain dari opsi 'next'.

Hal penting lain dalam perjanjian click-wrap yaitu penempatan kontrak atau fitur tersebut harus terlihat jelas oleh penerima kontrak. Selain itu, pihak yang memberikan penawaran harus dapat memastikan bahwa pihak penerima telah membaca syarat-syarat kontrak yang ditawarkan. Kemudian muncul pertanyaan, bagaimana agar pengguna membaca kesepakatan? Secara sistematis, si penawar harus mengatur sistem elektronik agar dia tidak bisa 'meng-klik' sebelum dia membaca kesepakatan yang telah ditawarkan. Hal tersebut diatur dengan 'scrolling' kotak dialog yang telah muncul. Jika pihak penawar tidak melakukan rancangan sistem seperti tersebut, maka perjanjianpun dapat batal karena telah melanggar syarat-syarat yang telah ditetapkan.

\section{Electronic Mail}

E-mail merupakan metode pengiriman pesan dalam sistem elektronik antar pengguna menggunakan Internet. Sementara e-mail mungkin merupakan pesan tunggal, tapi juga memiliki kemampuan untuk membuat suatu kontrak. Akibatnya, e-mail dipandang sebagai media komunikasi formal dan informal. Para pelaku bisnis sering menganggap pengaturan $e$ mail informal dan korespondensi bisnis sebagai acara non-kontrak. Oleh karena itu, mengirim e-mail, dengan atau tanda tangan, termasuk nama dan informasi kontak, dapat melambangkan persetujuan untuk pembentukan kontrak.

Jika pengadilan menyimpulkan bahwa pengirim berniat untuk mengakui isi suatu dokumen, mereka akan terikat dengan persyaratan. Sebaliknya, tanda terima dalam konteks kontrak elektronik tidak mengharuskan penerima mengetahui, membuka, atau membaca pesan, yang diperlukan hanyalah pesan elektronik tersedia untuk diproses oleh sistem informasi penerima.

\section{Electronic Signature}

Banyak terjadi pemahaman yang keliru tentang electronic signature yang dianggap sama seperti tanda tangan di atas kertas yang dipindai secara digital dengan menggunakan perjanjian elektronik, maka perlu untuk memahami apa yang tertulis dalam pasal 1 angka 12 UUITE, yaitu: "Tanda tangan elektronik adalah tanda tangan yang terdiri dari informasi elektronik yang dilampirkan, terkait atau terkait dengan informasi elektronik lainnya yang digunakan sebagai alat verifikasi dan otentikasi." 
Berdasarkan definisi tersebut, terdapat dua hal penting yang perlu mendapat perhatian dari pihak yang terlibat dalam internasional trade, yaitu verifikasi dan otentikasi. Untuk menandatangani e-contract, penandatangan perlu memverifikasi serta mengotentikasi data. Biasanya tanda tangan digital tidak berupa nama orang yang menandatanganinya. Caranya bisa dalam jenis barcode atau kode unik tertentu yang diverifikasi menggunakan PIN, password, finger print, dan lain-lain.

\section{Electronic Data Interchange (EDI)}

EDI adalah transmisi informasi antar komputer yang digunakan oleh pihak komersial yang sering membuat kontrak untuk mengirim dan menerima formulir standar umumnya berupa pesanan pembelian. Ini mungkin merupakan contoh paling jelas dari kontrak elektronik melalui penggunaan agen elektronik. Para pihak yang terlibat harus terlebih dahulu menyetujui persyaratan standar transaksi. Transaksi dikirim dan diterima setiap hari melalui saluran telepon antara agen elektronik (otomatis), tanpa keterlibatan manusia. EDI dapat mengurangi kerumitan yang terkait dengan pengiriman dan penerimaan informasi dalam jumlah besar, mengurangi kesalahan penekanan tombol. Pesanan pembelian otomatis adalah salah satu penggunaan EDI yang paling umum. Misalnya, sebuah toko besar menggunakan EDI untuk berulang kali memesan barang konsumsi dalam jumlah besar, seperti deterjen, untuk ribuan tokonya. EDI memungkinkan pemesanan dan pembuatan faktur barang-barang ini antar sistem komputer. Penawaran kontrak, penerimaan, dan persetujuan terjadi secara otomatis.

EDI adalah metode kontrak elektronik yang rumit karena output-nya dalam format teknis tertentu. Pesan dikodekan dalam bentuk yang telah disepakati secara nasional atau internasional yang dapat diterima secara umum dan dikirimkan melalui sistem store and forward. Efisiensi transaksi melalui kontrak elektronik cepat telah memperoleh persetujuan internasional dengan menggunakan metode komunikasi instan EDI dengan pengembangan EDIFACT (EDI for Administration, Commerce, and Transport).

Kontrak elektronik juga terjadi dalam penjualan software. Perangkat lunak umumnya dijual dalam empat cara: 1) penjualan langsung produk yang dikemas atau disesuaikan, 2) perjanjian lisensi, 3) langganan atau transaksi basis data, atau 4) penjualan online, yang menghasilkan pengiriman produk perangkat lunak atau unduhan otomatis. Dua jenis kontrak elektronik yang paling banyak digunakan perusahaan besar yaitu: kontrak "click-wrap" dan "shrink-wrap". Penjual perangkat lunak menentukan metode kontrak. Kontrak click-wrap, juga dikenal sebagai kontrak "browser-wrap", memungkinkan pembeli untuk menyatakan persetujuan terhadap persyaratan kontrak dengan mengklik tombol penerimaan yang muncul saat pembeli memperoleh atau menginstal produk. Pembeli tidak dapat mulai menggunakan software tersebut sampai mereka mengklik tombol yang menerima syarat dan ketentuan perjanjian.

\section{KESIMPULAN}

Aturan tentang kontrak elektronik mengenai Perdagangan Internasional di Indonesia masih diatur dalam Undang-Undang Nomor 11 Tahun 2008 tentang ITE dan UU Nomor 19 Tahun 2001 tentang Perubahan atas UU Nomor 11 Tahun 2011 tentang ITE. Selanjutnya diatur dalam PP Republik Indonesia Nomor 82 Tahun 2012 tentang Penyelenggaraan Sistem 
dan Transaksi Elektronik. Dalam Peraturan Pemerintah, tidak ada standar yang ketat dalam pelaksanaan kontrak elektronik. Hal yang berlaku di Indonesia tidak jauh berbeda dengan negara lain, karena mayoritas negara di dunia yang ikut melakukan Perdagangan Internasional belum memiliki aturan yang pasti dan jelas yang mengatur kontrak elektronik. Badan resmi PBB di bidang perdagangan yang menyangkut e-commerce yaitu UNCITRAL terus memperbaharui aturannya mengenai kontrak elektronik yang akan menjadi tolak ukur atau acuan bagi setiap negara yang melakukan perdagangan internasional, tidak terkecuali dengan Indonesia, agar setiap negara mempunyai aturan hukum yang pasti serta mengikat para pihak dan mempunyai sanksi.

\section{DAFTAR PUSTAKA}

Akhmaddhian, S., \& Agustiwi, A. (2016). Perlindungan Hukum Terhadap Konsumen Dalam Transaksi Jual Beli Secara Elektronik di Indonesia. UNIFIKASI: Jurnal Ilmu Hukum, 3(2), 40-60.

Cahyadi, A. D. (2019). Yurisdiksi Transaksi Elektronik Internasional Menurut UndangUndang Nomor 11 Tahun 2008 Tentang Informasi Dan Transaksi Elektronik. Jurnal Wawasan Yuridika, 3(1), 23-40.

Hanim, L. (2011). Pengaruh Perkembangan Teknologi Informasi Terhadap Keabsahan Perjanjian dalam Perdagangan Secara Elektronik (E-Commerce) di Era Globalisasi. Jurnal Dinamika Hukum, 11, 56-66.

Hasoloan, J. (2013). Peranan perdagangan internasional dalam produktifitas dan perekonomian. Edunomic Jurnal Pendidikan Ekonomi, 1(2).

Khairandy, R. (2001). Pembaharuan Hukum Kontrak sebagai Antisipasi Transaksi Electronic Commerce. Jurnal Hukum IUS QUIA IUSTUM, 8(16), 42-57.

Latianingsih, N. (2012). Prinsip Tanggung Jawab Pelaku Usaha dalam Transaksi Elektronik Menurut Undang-Undang Informasi dan Transaksi Elektronik. Ekonomi \& Bisnis, 11(2).

Malian, A. H. (2004). Kebijakan Perdagangan Internasional Komoditas Pertanian Indonesia. Analisis Kebijakan Pertanian, 2(2), 135-156.

Manap, M. A. (2018). Kontrak Elektronik: Isu dan Penyelesaian Undang-Undang. Journal of Law and Governance, 1(1), 62-76.

Nurhafni, N., \& Bintang, S. (2018). Perlindungan Hukum Konsumen dalam Perjanjian Baku Elektronik. Kanun Jurnal Ilmu Hukum, 20(3), 473-494.

Perdana, A., \& Dahlan, M. (2014). Penyelesaian Wanprestasi dalam Perjanjian Jual Beli Melalui Media Elektronik. Jurnal Ilmu Hukum, 2(1).

Putri, W. S. (2018). Keabsahan Kontrak Elektronik Dalam Transaksi E-Commerce Ditinjau Dari Hukum Perikatan. Jurnal Analisis Hukum, 1(2), 300-309.

Safitriani, S. (2014). Perdagangan internasional dan foreign direct investment di Indonesia. Buletin Ilmiah Litbang Perdagangan, 8(1), 93-116.

Setyawati, D. A., Ali, D., \& Rasyid, M. N. (2017). Perlindungan Bagi Hak Konsumen dan Tanggung Jawab Pelaku Usaha dalam Perjanjian Transaksi Elektronik. Syiah Kuala Law Journal, 1(3), 46-64.

Tan, Y. H., \& Thoen, W. (2003). Electronic Contract Drafting Based on Risk and Trust Assessment. International Journal of Electronic Commerce, 7(4), 55-71.

Wan, Z., Deng, R. H., \& Lee, D. (2015, November). Electronic contract signing without using trusted third party. In International Conference on Network and System Security (pp. 386-394). Springer, Cham. 